\title{
Modelling the impact of native pastures to examine the relative effects of land use change
}

\author{
$\underline{\text { C. Beverly }}^{\mathrm{a}}$, A. Southwell ${ }^{\mathrm{b}}$, A. Roberts ${ }^{\mathrm{a}}$, J. Virgona ${ }^{\mathrm{b}}$ and M. Hocking ${ }^{\mathrm{c}}$ \\ ${ }^{a}$ Department of Primary Industries, Rutherglen, Australia; \\ ${ }^{b}$ Department of Agricultural Systems and Extension, Charles Sturt University, Wagga Wagga, Australia; \\ ${ }^{c}$ Hocking et al Pty Ltd, Melbourne, Australia \\ Email: craig.beverly@dpi.vic.gov.au
}

\begin{abstract}
This paper describes (1) the development and validation of a native pasture model that accounts for species abundance, (2) the integration of the native pasture model into a catchment framework and (3) the likely biophysical trade-offs associated with increasing the proportion of native perennial pasture species within a pilot catchment. The rationale for developing the model was to build on the conceptualisation of contemporary pasture models and include new algorithms that better represent native grass species commonly found in temperate climate regions of Australia. The native pasture model is phenologically based and simulates both daily pasture growth and soil water dynamics. It was developed and validated against data from field experiments conducted at Wagga Wagga in NSW, Australia, for two native grass species, Austrodanthonia spp. (winter dominant $\mathrm{C}_{3}$ ) and Bothriochloa macra (summer dominant $\mathrm{C}_{4}$ ). The model predicted seasonal pattern and inter-annual variation of soil moisture contents and green leaf area index $(G L A I)$ for various planting densities. There was a high correlation between the simulated and measured soil moisture contents $\left(\mathrm{r}^{2}=0.81, \mathrm{p}<0.0001\right.$ for Austrodanthonia spp; $\mathrm{r}^{2}=0.73, \mathrm{p}<0.0001$ for Bothriochloa macra) and GLAI $\left(\mathrm{r}^{2}=0.66, \mathrm{p}<0.0001\right.$ for Austrodanthonia spp; $\mathrm{r}^{2}=0.83, \mathrm{p}<0.0001$ for Bothriochloa macra) at actual measurement dates.
\end{abstract}

The native pasture model was integrated into a physically-based catchment modelling framework (Catchment Analysis Tool, CAT) to provide a flexible platform for simulating the environmental impacts of various pasture management options and the likely consequences of land use changes on catchment dynamics. This catchment model comprises numerous vegetation modules (including cropping, forestry and alternative pasture models) of varying complexity. An example of how the native pasture model can be used within the CAT framework is described by the application to the Bet Bet catchment which has been identified as a high salt exporting catchment within the Murray Darling Basin of Australia. The Bet Bet catchment currently yields and exports annually approximately 36,056 ML and 20,000 tonnes of salt respectively. The grazing of unimproved pastures is the dominant land use within the catchment such that economically viable options for increasing perenniality in the catchment are limited to working with the native perennial grasses already present and targeted tree planting. The study evaluated the water yield, saturated area and salt load trade-offs associated with increasing the proportion of native perennial pasture species. Scenarios considered varying proportions of summer or winter dominant native pastures across the catchment in comparison to reafforestation. Results indicate that complete reafforestation of the grazing area would reduce both stream flow and salt exports, by 6,299 $\mathrm{ML} \mathrm{yr}^{-1}$ and 10,486 tonnes salt $\mathrm{yr}^{-1}$ respectively. Complete catchment coverage of Bothriochloa macra was estimated to increase stream flow by 3,987 ML $\mathrm{yr}^{-1}$ as well as to reduce groundwater inflows by $1,429 \mathrm{ML} \mathrm{yr}^{-1}\left(2,745\right.$ tonnes salt $\left.\mathrm{yr}^{-1}\right)$. In contrast, Austrodanthonia spp. pasture was estimated to increase stream flow by $4,378 \mathrm{ML} \mathrm{yr}^{-1}$ and increase salt export by 714 tonnes salt $\mathrm{yr}^{-1}$. Targeted restoration of either summer or winter dominant native pastures within the steeper regions of the catchment with slopes greater than $5 \%$ (representing $11 \%$ of the catchment area) was considered. Results show that restoration of Bothriochloa macra in the upper catchment increased stream flow by $132 \mathrm{ML} \mathrm{yr}^{-1}$ and reduced salt loads by 472 tonnes salt $\mathrm{yr}^{-1}$, whereas restoration of Austrodanthonia spp. increased stream flow by 409 ML $\mathrm{yr}^{-1}$ and reduced salt loads by 109 tonnes salt $\mathrm{yr}^{-1}$. In contrast, reafforestation in the upper catchment

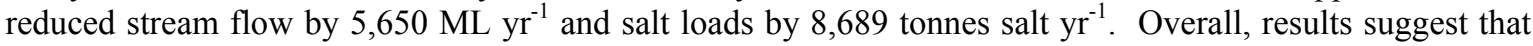
increasing the proportion of summer active native perennial grasses across large parts of the catchment may be an effective salinity management option for reducing recharge and salt loads to rivers.

Integration of a validated native pasture model into the CAT framework is shown to provide the capability to simulate the long-term effects of land use changes in the landscape on catchment dynamics.

Keywords: Native pasture model, Catchment Analysis Tool (CAT), catchment yield and salt export. 
Beverly et al., Modelling the impact of native pastures to examine the relative effects of land use change.

\section{INTRODUCTION}

Australia is estimated to have approximately 190 Mha of unimproved pasture (ABS, 2008), the majority of which are grasses which are indigenous (native) to Australia. Whereas many of the introduced species that have their origins in Europe, Asia, Africa and other parts of the world are considered more nutritious and have been widely adopted and extensively used in grazing enterprises, many of the native grasses are drought resistant and require low fertiliser and management inputs (CSU, 2009). These characteristics make them suitable for inclusion into an integrated grazing system, particularly in low rainfall areas. To assess the environmental and productivity impacts of different management strategies aimed at utilising native pasture grazing systems requires the application of a biophysical catchment model. However few catchment scale biophysical models adequately describe the phonological dynamics that distinguish different pasture species.

Three one-dimensional biophysical models have been extensively used to model native pastures in Australia, namely GRASP (McKeon et al., 1982), GRASSGRO (Freer et al, 1997) and the SGS pasture model (Johnson, 2008). GRASP has been designed to model native pastures in tropical and sub-tropical environments of Northern Australia. Originally based on the pasture production model outlined by McKeon et al. (1982), GRASP is mechanistic by nature though algorithms within the model are empirically derived. It does not simulate phenological development of the sward and consequent changes in root:shoot partitioning, nor does it simulate some components of the soil water balance (such as run-on, lateral drainage or unsaturated flows in saturated soils) or animal behavioural attributes.

In contrast, GRASSGRO combines animal, soil moisture and pasture growth models with management regime to simulate pasture and animal production of grazing enterprises (Moore et al. 1997; Clark et al. 2000) at a number of locations and soil types using a daily time-step with the only input data required being daily meteorological data. The GRASSGRO decision support tool also has the capability to simulate simple grazing production systems with outputs including an economic analysis and a simple soil water balance.

The Sustainable Grazing Systems (SGS) Pasture Model was developed as part of the Sustainable Grazing Systems National Experiment for the purpose of analysing data and processes within the national experimental sites (Johnson et al., 2003). The model simulates water dynamics, nutrient dynamics, herbage accumulation, animal growth and management on a daily timestep. The underlying model conceptualisation philosophy was to simplify complex processes whilst ensuring appropriate system behaviour in addition to providing the user with an interface that enables most parameters to be modified. Johnson et al. (2003) highlighted the need to balance complexity, realism and tractability with simple parameterisation. Whilst specific parameter profiles for some of the introduced temperate species (e.g. phalaris, annual ryegrass, perennial ryegrass) have been constructed, generic native perennial grass profiles were created for both $\mathrm{C} 3$ and $\mathrm{C} 4$ grasses.

Catchment-scale biophysical models typically use generic vegetation modules to estimate transpiration under various land-uses. For instance, SWAT (Neitsch et al., 2001) adopts a heat unit approach to represent all land uses. More broad-scale catchment models (SIMHYD) typically estimate transpiration based on the FAO56 crop factor approach. In contrast, the Catchment Analysis Tool (CAT) comprises many farming systems models linked within a catchment framework with allowance for landscape connectivity and connection to a distributed, multi-layered groundwater model (Beverly et al. 2005). This catchment model was selected to integrate the developed native pasture sub-model as the catchment model construct facilitates incorporation of different pasture/crop/tree modules of varying complexity. It was deemed computationally efficient to undertake development of a native pasture model that incorporates concepts previously published with revision to account for plant abundance or density.

This paper describes the development of a native pasture growth model to further investigate the role of key morphological features for water use possessed by the grasses Austrodanthonia spp. and Bothriochloa macra and the embedment of this model into the CAT with application to the Bet Bet catchment.

\section{THE NATIVE PASTURE MODEL}

\subsection{Overview}

The native pasture model uses a mass balance approach to estimate soil/water/plant interactions on a daily timestep. Daily pasture growth is represented using the phenological concepts embedded in a number of contemporary dynamic biophysical pasture models (Littleboy and McKeon, 1997; Johnson et al., 2003; Moore et al., 1997) designed to simulate daily pasture growth and soil water dynamics. The model assumes that plant growth is based on a cycle of phenology to describe net primary production, assimilate partitioning 
Beverly et al., Modelling the impact of native pastures to examine the relative effects of land use change.

between root, shoot and stems, decay functions and root mobilisation processes. The allocation and transfer of biomass from immature development through to dead/litter and ultimately null, is controlled by a series of decay functions. The model is capable of simulating a series of swards that compete based on root development and intercepted light. The physiological status of the plant through these cycles is expressed through several discreet phenostages, (vernalisation, vegetative, reproductive, flowering and postreproductive) influenced by, and incorporating, a variety of different environmental controls. Additionally, transitions between stages are governed by elapsed time or incrementing environmental variation. The phenological status influences the allocation of net primary production (NPP) throughout the system but does not control the amount of NPP produced. A full description of the model is detailed in DPI (2009).

The model was constructed to simulate a native grass experiment conducted at Wagga Wagga, NSW, whereby the $\mathrm{C}_{3}$ grass Austrodanthonia spp. and the $\mathrm{C}_{4}$ grass Bothriochloa macra were planted in a randomised complete block design at four planting densities $\left(4,9,16\right.$ and 25 plants $\left./ \mathrm{m}^{2}\right)$ and monitored for changes in soil water content to a depth of $180 \mathrm{~cm}$.

A tissue pooling system similar to that of the SGS model (Johnson et al., 2003) was used to describe the overall biomass/energy transfer system with aboveground photosynthates passing through immature, mature, senescing and dead phases on the way to a litter pool and eventually a null pool which returns carbon to the soil. The rate at which this material passes through these pools is species specific, though increases with increasing temperature and decreasing soil moisture.

\subsection{Key model enhancements}

Consistent with GRASSGRO (Moore et al., 1997), net primary production is a function of solar radiation and light interception, with limitations on growth based on soil moisture status, water logging and temperature. Available light is a function of green leaf area index (GLAI) which has been modified from Freer et al. (1997) to contain a shading function as found in Equation 1.

$$
A L_{j}=\left(\frac{1-\exp \left(-k_{j} G L A I_{j}\right)}{1-\exp \left(-k_{i} G L A I_{i}\right)}\right) \cdot\left(1-\left(\text { Glfshade }_{j}\right)\right.
$$

where $A L j$ is the available light for species $j, k j$ is the average extinction coefficient for species $j, G L A I j$ is the green area index of a species' established or seedling plants for either species $j$ or for the entire pasture $i$ and Glfshade $_{j}$ is the available light limitations due to shading by pasture biomass

The shading function is sigmoidal in shape and relates potential light interception to pasture biomass (Equation 2). As native pastures often retain a proportion of standing dead between seasons, it was necessary to account for this to prevent overproduction when allowed to grow tall and rank.

$$
\text { Glfshade }_{j}=1-\left(0.9\left(\operatorname{SIG}\left(B_{\min }, B_{\max }, \operatorname{shdsh} p\right)\right)\right)
$$

where Bmin is the minimum biomass levels for the pasture where shade impacts available light, Bmax is the maximum biomass levels for the pasture above which biomass has no additional impact on available light and shdshp is the curvature function for biomass and shading. The sigmoidal function is based on Freer et al (1997) as defined by

$$
\operatorname{SIG}(x, a, b)=\left(1+\exp \left(-\frac{2(\ln (0.95)-\ln (0.05))}{b-a}\left(x-\frac{a+b}{2}\right)\right)\right)^{-1}
$$

where $x, a$ and $b$ represent $B_{\min }, B_{\max }$ and $s h d s h p$ respectively

Two options were developed to explain the relationship between actual basal area and the basal area coefficient, one mechanistic in nature, the other empirical. The mechanistic basal equation assumes a sigmoidal function exists between the minimum and maximum potential basal area. An actual basal area of 0.3 was assumed to equate to maximum potential growth thus leading to Equation 4.

$$
K_{B A, j}=1-\exp \left(-12 x_{j}\right)^{4}
$$

where $K_{B A, j}$ is the basal area coefficient for species $j$ and $x_{j}$ is the user defined basal area of species $j$. 
Beverly et al., Modelling the impact of native pastures to examine the relative effects of land use change.

The second basal equation was formulated from a non-linear regression analysis of daily growth during the growing season (October and November for Austrodanthonia spp.) to basal area for each species. Userdefined parameters $K_{B 1}$ and $K_{B 2}$ were derived from this relationship for each species and incorporated into the power function in Equation 5.

$$
K_{B A, j}=K_{B 1, j} x_{j}^{K_{B 2, j}}
$$

where $K_{B A, j}$ is the basal area coefficient for species $j, x_{j}$ is the user defined basal area of species $j, K_{B 1, j}$ is the user defined coefficient for species $j$ and $K_{B 2, j}$ is the user defined exponent for species $j$.

Other key modifications include temperature and water logging growth limiting factors, various root distribution functions, fertility impacts on net primary production and phenostage growth partition ratios as reported in Southwell (2009).

\subsection{Parameter estimation}

Key parameters, namely specific leaf area, root distributions and basal area, were set based on the experimental data collected whereas other values were based on reported estimates from the literature (e.g. Robinson and Archer, 1988; Cook et al., 1976), or else were set based on anecdotal observation. Parameters associated with processes not directly measured such as coefficients describing response curve shape were set using the non-linear parameter estimation software package PEST (Doherty, 1994). This software performed iterations comparing modelled with observed LAI and soil water data using weighted least-squares to estimate parameter values that most satisfactorily reproduce observed outcomes.

\subsection{Pasture growth}

The correlation coefficient (r) between all measured GLAI data and modelled data was 0.93 as seen in Table 1 with a corresponding regression coefficient $\left(\mathrm{r}^{2}\right)$ of 0.82 . When considered with least squares regression intercept (b) and least squares regression slope (a) values close to 0 and 1 respectively, this suggests that the model predictions are reasonable when compared to observed values of GLAI. Overall, the root mean square error as a percentage of the mean ( $\% \mu \mathrm{RMSE})$ for all data was only $12.67 \%$, reducing to $7.67 \%$ and $8.23 \%$ at the Bothriochloa macra $(B)$ and Austrodanthonia spp. (D) species level respectively.

\subsection{Soil moisture}

The relationship between soil water deficit observations and modelled estimates are summarised in Table 2. The correlation coefficient ( $r$ ) for all data was calculated to be 0.91 (Table 2) with a corresponding regression coefficient $\left(\mathrm{r}^{2}\right)$ of 0.87 . Correlation values decreased with decreasing density for the Austrodanthonia spp. treatments. This did not
Table 1: Statistics of predicted to observed green leaf area (GLAI) for all data, Bothriochloa macra (B) treatments, Austrodanthonia spp. $(D)$ treatments and the two species at each of the planting densities of 4, 9, 16 and 25 plants $\mathrm{m}^{-2}$

\begin{tabular}{|l|l|l|l|l|l|}
\hline & $\mathrm{b}$ & $\mathrm{a}$ & $\mathrm{r}$ & $\mathrm{r}^{2}$ & $\mathrm{RMSE}$ \\
\hline All data & 0.018 & 0.92 & 0.93 & 0.82 & 0.016 \\
\hline B.macra (B) & 0.043 & 0.90 & 0.93 & 0.83 & 0.014 \\
\hline Aust.spp (D) & 0.002 & 0.84 & 0.93 & 0.66 & 0.005 \\
\hline 4B & 0.045 & 1.03 & 0.91 & 0.84 & 0.019 \\
\hline 9B & 0.043 & 0.70 & 0.95 & 0.87 & 0.032 \\
\hline 16B & 0.032 & 1.00 & 0.94 & 0.89 & 0.025 \\
\hline 25B & 0.031 & 0.11 & 0.95 & 0.83 & 0.035 \\
\hline 4D & 0.002 & 0.43 & 0.92 & 0.26 & 0.008 \\
\hline 9D & 0.002 & 0.66 & 0.94 & 0.32 & 0.007 \\
\hline 16D & 0.006 & 0.82 & 0.95 & 0.48 & 0.007 \\
\hline 25D & 0.038 & 0.75 & 0.95 & 0.68 & 0.015 \\
\hline
\end{tabular}

Table 2: Statistics of predicted to observed soil water deficit (SWD) for all data, Bothriochloa macra $(B)$ treatments, Austrodanthonia spp. $(D)$ treatments and the two species at each of the planting densities of $4,9,16$ and 25 plants $\mathrm{m}^{-2}$.

\begin{tabular}{|l|l|l|l|l|l|}
\hline & $\mathrm{b}$ & $\mathrm{a}$ & $\mathrm{r}$ & $\mathrm{r}^{2}$ & RMSE \\
\hline All data & 18.47 & 0.91 & 0.91 & 0.87 & 20.87 \\
\hline B.macra (B) & 32.60 & 0.81 & 0.83 & 0.87 & 28.80 \\
\hline Aust.spp (D) & 2.87 & 1.11 & 0.81 & 0.87 & 15.92 \\
\hline 4B & 29.32 & 0.95 & 0.92 & 0.84 & 34.86 \\
\hline 9B & 39.34 & 0.78 & 0.93 & 0.91 & 30.50 \\
\hline 16B & 20.03 & 0.84 & 0.94 & 0.89 & 22.60 \\
\hline 25B & 35.09 & 0.79 & 0.91 & 0.91 & 25.74 \\
\hline 4D & -5.41 & 1.16 & 0.52 & 0.85 & 14.37 \\
\hline 9D & 0.68 & 1.24 & 0.57 & 0.89 & 18.43 \\
\hline 16D & 1.81 & 1.13 & 0.70 & 0.90 & 14.32 \\
\hline 25D & 13.16 & 0.97 & 0.83 & 0.91 & 16.19 \\
\hline
\end{tabular}


Beverly et al., Modelling the impact of native pastures to examine the relative effects of land use change.

occur for Bothriochloa macra though least squares regression intercept values (b) were further from the origin.

\section{CATCHMENT MODEL}

The modelling approach used the Catchment Analysis Tool (CAT) framework (Beverly et al., 2005; DPI, 2009) to assess the on-site and off-site impacts of various vegetation restoration strategies to reduce catchment salt exports. This model uses a combination of a suite of farming system models linked within a catchment framework with allowance for landscape connectivity. The farm-scale models range in complexity from a simple crop factor approach to phenologically based crop, pasture and forest growth modules and account for position in the landscape (topography, soil type, aspect and slope), climate, land use and land management and simulate water balance, nutrient transport and production on a daily time step. A common water balance, erosion, nutrient, carbon and soil evaporation module is used by all the available crop-growth models. The CAT has also been developed to link with the fully distributed multi-layer groundwater model MODFLOW (McDonald and Harbaugh, 1988) to account for groundwater dynamics and provide a whole-of-catchment water balance whereby recharge estimates from the farming system models are explicitly incorporated into the groundwater model.

\section{THE BET BET CATCHMENT APPLICATION}

\subsection{Model application objectives}

The integration of the native pasture model into the catchment framework was evaluated by application to the Bet Bet catchment which is located in North Central Victoria, Australia (Figure 1). The Bet Bet catchment covers approximately 64,432 ha and is predominantly used for grazing (71\%) with $19 \%$ being treed and the remaining $10 \%$ being categorised as towns, roads and water bodies and horticulture. A major objective of this study was to assess the potential consequence of future land-use options on the catchment hydrology and salt balance. Six scenarios were carried out using the CAT framework utilising the native pasture model to examine (a) the impact of applying the native pasture model on estimates of catchment hydrology compared to previous hydrologic estimates derived using a simple pasture model, and (b) the impact of changing from a predominantly $\mathrm{C} 3$ pasture to a $\mathrm{C} 4$ pasture. Six scenarios were considered, namely: (1) current land use with pasture being represented by an unimproved pasture; (2) current land use with $\mathrm{C} 3$ native pasture replacing all previous pastures; (3) current land use with C4 native pasture replacing all previous pastures; (4) restoring $\mathrm{C} 3$ native pasture on land classes of greater than 5\% slope in the upper Bet Bet creek study area; (5) restoring $\mathrm{C} 4$ native pasture on land classes of greater than $5 \%$ slope in the upper Bet Bet creek study area; (6) replacement of all grazed pasture with trees across all land classes. Simulated depth to watertable, stream yield, and change in salt loads were compiled for each scenario.

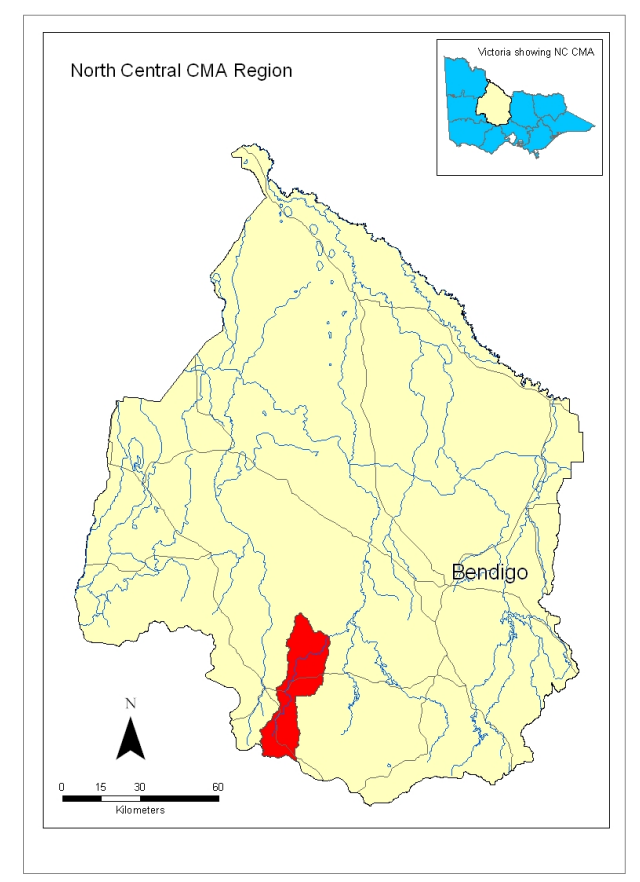

Figure 1. Location of the Bet Bet catchment within the North Central Catchment Management Area of Victoria, Australia

\subsection{Calibration of the Bet Bet model}

The linked surface water/groundwater Bet Bet catchment model was calibrated based on matching streamflow, salt loads and groundwater hydrograph data for the period 1974-2000. Streamflow results were also compared to the Loddon REALM Model (SKM 2004). The mean annual results derived using the CAT for baseflow and streamflow were $17 \mathrm{~mm} / \mathrm{yr}$ and $55 \mathrm{~mm} / \mathrm{yr}$ respectively compared to REALM estimates of 
Beverly et al., Modelling the impact of native pastures to examine the relative effects of land use change.

$13 \mathrm{~mm} / \mathrm{yr}$ and $57 \mathrm{~mm} / \mathrm{yr}$. A coefficient of determination of 0.71 was derived based on comparing monthly observed versus predicted streamflow with a Nash-Sutcliffe Index (NSI) (Nash and Sutcliffe, 1970) of 0.74.

A multi-layered distributed MODFLOW groundwater model had previously been developed (Beverly et al., 2008) for the Bet Bet catchment and calibrated for the period 1974 to 2000 inclusive using groundwater bore hydrograph datasets and mapped discharged site information. This model was used in the current study to estimate the potentiometric surface and groundwater discharges under various land-use scenarios. The calibrated groundwater model estimated an area of 16,200 ha to be subject to high watertables less than 1.5 metres from surface which was in agreement with the groundwater discharge based on aerial photographs of 15,500 ha.

Table 3: Mean annual water balance components $(\mathrm{mm} / \mathrm{yr})$ for each scenario considered. Also summarized are the corresponding saturated areas and changes in stream flow and salt export relative to current practice.

\begin{tabular}{|c|c|c|c|c|c|c|}
\hline \multirow[b]{2}{*}{ Scenario } & 1 & 2 & 3 & 4 & 5 & 6 \\
\hline & $\begin{array}{l}\text { Current } \\
\text { practice }\end{array}$ & B. macra & Austrod. & $\begin{array}{l}\text { B. macra on } \\
\text { slopes }>5 \%\end{array}$ & $\begin{array}{l}\text { Austrod. on } \\
\text { slopes }>5 \%\end{array}$ & $\begin{array}{c}\text { Tree with } \\
\text { fixed canopy }\end{array}$ \\
\hline \multicolumn{7}{|l|}{ Water Balance (mm/year): } \\
\hline Rainfall & 557.2 & 557.2 & 557.2 & 557.2 & 557.2 & 557.2 \\
\hline Soil evaporation & 188.1 & 175.1 & 149.7 & 186.7 & 183.5 & 203.9 \\
\hline Transpiration & 298.8 & 315.4 & 327.1 & 301.2 & 302.6 & 330.4 \\
\hline Evapotranspiration & 486.9 & 490.5 & 476.8 & 487.9 & 486.0 & 534.4 \\
\hline Quick flow & 22.1 & 28.4 & 29.0 & 22.3 & 22.7 & 12.1 \\
\hline Recharge & 47.5 & 38.9 & 51.7 & 46.3 & 47.8 & 12.5 \\
\hline \multicolumn{7}{|l|}{ Saturated area (ha) } \\
\hline$<2.0 \mathrm{~m}$ & 5,368 & 4,181 & 5,612 & 5,070 & 5,149 & 1,755 \\
\hline$<1.0 \mathrm{~m}$ & 733 & 515 & 785 & 689 & 718 & 155 \\
\hline$<0.1 \mathrm{~m}$ & 186 & 106 & 197 & 167 & 176 & 37 \\
\hline \multicolumn{7}{|c|}{ Changes relative to Scenario 1 . } \\
\hline Recharge (\%) & 0 & -18.0 & 9.0 & -2.4 & 0.7 & -73.8 \\
\hline Stream flow* (ML/year) & 0 & 3,987 & 4,378 & 132 & 409 & $-6,299$ \\
\hline Salt output (t/year) & 0 & $-2,745$ & 714 & -472 & -109 & $-10,486$ \\
\hline
\end{tabular}

\subsection{Scenario results}

The key mean annual water balance components for each of the six scenarios considered are summarised in Table 3. These results are based on 1957 to 2005 modelled daily estimates. Also summarised are the associated long term changes in areas associated with various shallow depth-to-watertables. Scenarios 2 (Bothriochloa pasture replacing existing unimproved pasture throughout the catchment) and 6 (reafforestation) were found to have the greatest impact on groundwater dynamics in the Bet Bet catchment, reducing recharge by $18 \%$ and $74 \%$ respectively (Table 3) relative to Scenario 1 (current practice with unimproved pasture). As a consequence, less groundwater base flow was predicted to occur, reducing salt output from the catchment by 2,745 and 10,486 tonnes annually (Scenarios 2 and 6 respectively). Annual stream flow was also reduced in Scenario 6 by 6,299 $\mathrm{ML} \mathrm{yr}^{-1}$; however, due to greater quick flow in Scenario 2, stream flow increased by 3,987 $\mathrm{ML} \mathrm{yr}^{-1}$. Scenario 3 (Austrodanthonia pasture) increased recharge $(9 \%)$, stream flow $\left(4,378 \mathrm{ML} \mathrm{yr}^{-1}\right)$ and salt output (714 tonnes salt $\left.\mathrm{yr}^{-1}\right)$ relative to Scenario 1.

\section{DISCUSSION AND CONCLUSIONS}

The developed native pasture model has been shown capable of estimating differences in soil water deficit and green leaf area index for summer and winter dominant growth native pastures. Integration of this model into the CAT catchment modelling framework provides the capability to simulate the long-term effects of 
Beverly et al., Modelling the impact of native pastures to examine the relative effects of land use change.

land use changes in the landscape, such as pasture/crop/woodland conversions, on catchment dynamics. The results have shown the potential benefit of a highly summer dominant pasture on catchment hydrology with differences between the two native species evident, suggesting that increasing the proportion of summer active native perennial grasses across large parts of the catchment may be an effective salinity management option for reducing recharge and salt loads to rivers whilst enhancing water quality.

\section{REFERENCES}

ABS (2008). National Regional Profile, Australian Bureau of Statistics, http://www.census.abs.gov.au/.

Beverly, C, Hocking, M., Wilford, J. and Lawrie, K. (2008). Building more robust hydrological models underpinned by new regolith-landform information. 2nd International Salinity Conference, Adelaide.

Beverly, C., Bari, M., Christy, B., Hocking, M. and Smettem, K. (2005). Predicted salinity impacts from land use change: comparison between rapid assessment approaches and a detailed modelling framework. Australian Journal of Experimental Agriculture, 45, 1453-1469.

Clark, S.G., Donnelly, J.R. and Moore, A.D. (2000). The GRASSGRO decision support tool: its effectiveness in simulating pasture and animal production and value in determining research priorities. Australian Journal of Experimental Agriculture, 40, 247-256.

Cook, S.J., Lazenby, A. and Blair, G.J. (1976). Comparative responses of Lolium perenne and Bothriochloa macra to temperature, moisture, fertility and defoliation. Australian Journal of Agricultural Research, 27, 769-778.

CSU, HSC online, Extract from Stage 6 Agriculture Syllabus NSW Board of Studies Amended 2009, http://hsc.csu.edu.au/agriculture/production/native_pastures/native_gra.htm.

Doherty, J. (1994). PEST: a unique computer program for modelling independent parameter optimisation. In 'Water Down Under 94'. Adelaide pp. 551-554 (The Institution of Engineers, Australia: Barton, ACT).

DPI (2009). Models of the Catchment Analysis Tool (CAT1D Version 32), August 2009, Technical Reference Manual, C. Beverly (ed.), Department of Primary Industries, ISBN: 978-1-74217-681-9, 214pp.

Freer, M., Moore, A.D. and Donnelly, J.R. (1997). GRAZPLAN: Decision support systems for Australian grazing enterprises. II. The animal biology model for feed intake, production and reproduction and the GrazFeed DSS. Agricultural Systems, 54, 77-126.

Johnson, I.R. (2008). Biophysical modelling: Documentation of the DairyMod, EcoMod and SGS Pasture Model. IMJ Consultants Pty Ltd, Armidale, NSW, Australia, 149pp.

Johnson, I.R., Lodge, G.M. and White, R.E. (2003). The sustainable grazing systems pasture model: description, philosophy and application to the SGS national experiment. Australian Journal of Experimental Agriculture, 43, 711-728.

Littleboy, M. and McKeon, G.M. (1997). 'Subroutine GRASP: Grass production model. Documentation of the Marcoola version of Subroutine GRASP. Appendix 2 of Evaluating the risks of pasture and land degradation in native pasture in Queensland.

McDonald, M.C. and Harbaugh, A.W. (1988). 'MODFLOW, A modular three-dimensional finite difference ground-water flow model.' US Geological Survey, Washington DC.

McKeon, G.M., Rickert, K.G., Cooksley, D. and Scattini, W.J. (1982). Pasture production model. In 'Proceedings Australian Society of Animal Production' pp. 201-4).

Moore, A.D., Donnelly, J.R. and Freer, M. (1997). GRAZPLAN: Decision support systems for Australian grazing enterprises.III. Pasture growth and soil moisture submodels, and the GrasGro DSS. Agricultural Systems 55, 535-582.

Nash, J.E. and Sutcliffe, J.V. (1970). River flow forecasting through conceptual models, 1. A discussion of principles. Journal of Hydrology, 10, 282-290.

Neitsch, S.L., Arnold, J.G., Kiniry, J.R. and Williams, J.R. (2001). Soil Water Assessment Tool Theoretical Documentation, Version 2000. (Grassland, Soil and Water Research Laboratory, Temple, Texas).

Robinson, G.G. and Archer, K.A. (1988). Agronomic potential of Native Grass Species on the Northern Tablelands of New South Wales. 1. Growth and herbage production. Australian Journal of Agricultural Research 39, 415-423.

SKM (2004). Upper Loddon REALM model update. Sinclair Knight Merz, 100pp.

Southwell, A.F. (2009). Factors influencing the soil water dynamics beneath native perennial pastures in the High Rainfall Zone of south-eastern Australia. Doctor of Philosophy thesis, Charles Sturt University, 286pp. 